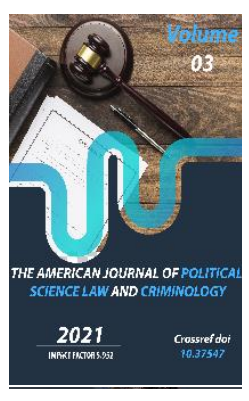

\title{
Execution Of Punishment In The Form Of Restriction Of Freedom In The Republic Of Uzbekistan
}

\author{
Olimova Dilshoda \\ Master's Degree Student Of Tashkent State Law University, 100047, Tashkent, Uzbekistan
}

Journal Website: http://usajournalshub.c om/index,php/tajpslc

Copyright: Original content from this work may be used under the terms of the creative commons attributes 4.0 licence.

\section{ABSTRACT}

The article discusses the issues of the execution of punishment in the form of restriction of freedom in the Republic of Uzbekistan, a comparative legal analysis of the execution of punishment in the form of restriction on the basis of foreign experience, the problems and ways of improving the order of execution of punishment in the form of restriction of freedom are presented.

\section{KEYWORDS}

Restriction of freedom, inspection, electronic tracking devices, probation, electronic bracelet.

\section{INTRODUCTION}

To implement judicial and legal reforms and liberalize criminal punishment, the Law of the Republic of Uzbekistan dated August 10, 2015 "On Amendments and Additions to Certain Legislative Acts of the Republic of Uzbekistan" introduced a new type of punishment into the system of criminal punishment: "Article 43, clause. "D1" - restriction of freedom ", in connection with which the Criminal Code of the Republic of Uzbekistan was supplemented with articles 481 " Restriction of freedom "and

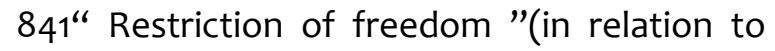


minors). The inclusion of restriction of freedom as an alternative to imprisonment not related to the isolation of the convict from society in accordance with the Law of the Republic of Uzbekistan dated 08/10/2015 is a direct manifestation of the humanization of the country's criminal legal policy.

The essence of the restriction of freedom under our legislation lies in the attitude of the convict, a complete ban on leaving the home under one pretext or another, or restrictions on leaving the home at a certain time of the day.

\section{MATERIALS AND METHODS}

The procedure for the execution of the penalty of restriction of freedom is enshrined in Chapter 81 of the Criminal Executive Code of the Republic of Uzbekistan. It streamlines the procedure for the execution of punishment, the timing of calculation, the procedure for serving a sentence, responsibility for violating the order and conditions for serving a sentence in the form of restriction of freedom. The legal basis for the activities of criminal executive inspectorates is also the Order of the Ministry of Internal Affairs of the Republic of Uzbekistan No. 157 "Instructions on the procedure for organizing the execution of sentences in the form of deprivation of a certain right, correctional labour and restriction of freedom and control over conditionally convicted persons" [1].

In particular, this decree defines the general rules for the execution of punishment, the duties of convicts, the execution of a court sentence, control over the behaviour of convicts, and deregistration of those convicted of restriction of liberty. In accordance with article 441 of the Criminal Executive Code of the Republic of Uzbekistan, the execution of punishment is carried out by the inspection of the execution of the internal affairs bodies at the place of residence of the convict or by another body determined by the court, designed to supervise the observance by the convicts of the prohibitions (restrictions) established by the court.

In contrast to the criminal executive law of Russia, in the Republic of Kyrgyzstan, as in the Republic of Uzbekistan, an internal affairs body for the execution of punishment has been elected as the body for the enforcement of the restriction of freedom. Convicted to restriction of freedom must comply with the prohibitions (restrictions) established by the court, and also be upon being summoned to the Inspectorate for the Execution of Sentences to give oral or written explanations on issues related to the serving of the sentence.

The inspectorate of the internal affairs bodies conducts interviews with convicts, explains the procedure and conditions for serving the sentence, also has the right to receive information at the place of work and study of the convict and, if necessary, meet with the administration at the place of work and study of the convict. If necessary, electronic means of tracking can be applied to the convicted person to whom this type of punishment has been applied.

For round-the-clock observation of prisoners sentenced to restraint of liberty, all technical means are installed on-duty units of the internal affairs bodies. If it is established that the duties imposed on the convicted person have been violated, the duty officer immediately notifies the punishment enforcement inspectorate, and the 
inspectorate takes measures, clarifies the situation and eliminates them.

If the convicted person violates the rules for using electronic means of tracking, while serving the sentence, the punishment enforcement inspectorate submits a petition to the court to replace the unserved term of restriction of freedom with another type of punishment.

If the convicted person causes problems with the use of electronic means of tracking, the Inspectorate for the Execution of Sentences sends the prosecutor a document for filing a claim with documents attached to it on taking measures to recover material damage from the convicted person. The Inspectorate for the Execution of Sentences and the Prosecutor permit to leave the place of residence at a certain time, to visit certain places located within the relevant administrative territory, or to leave the relevant administrative territory, as well as permission to change the place of residence.

The decision is made in exceptional cases, based on the nature of the prohibitions (restrictions), the personality of the convict, his behaviour, and the availability of supporting documents.

\section{RESULTS AND DISCUSSION}

In accordance with part 5 of article 443 of the Criminal Executive Code, if the convicted person during the period of serving the sentence realizes his criminal acts, and firmly takes the path of correction, compensates for the material and moral damage caused, the punishment enforcement inspectorate submits to the court a submission to cancel in full or in part previously established convicted person of prohibitions (restrictions). The peculiarity of this paragraph is that its basis is the purpose of punishment - i.e. correction of the convict. Thus, this paragraph ensures the right of obedient behaviour of convicts, encourages them to comply with the regime.

This clause must be distinguished from parole from serving a sentence following Article. 73 of the Criminal Code of the Republic of Uzbekistan. The differences between the institutions under consideration are that a prerequisite for conditional early release from serving a sentence provides for the serving of a certain period of the assigned sentence, while Part 5 of the Criminal Code 481 does not provide for terms of serving a sentence to be exempted from prohibitions (restrictions). In addition, Article 73 of the Criminal Code of the Republic of Uzbekistan establishes a full exemption from punishment with all restrictions (prohibitions), and on the basis of Article 481 part 5 of the Criminal Code, the court can cancel in whole or in part the additional prohibitions (restrictions) previously established for the convicted person, without exemption from the established by the court of punishment in the form of a complete ban on leaving the home under one pretext or another, or restrictions on leaving the home at a certain time of the day, as well as from those imposed on the convicted person. The term of restriction of freedom is calculated from the day the convicted person is registered with the punishment enforcement inspectorates. Both supporters and opponents of this punishment are interested in the issue of the implementation of the restriction of freedom in developed countries. For example, in the USA the probation service is a punishment in the form of restraint of liberty. This type of punishment is provided for by the US Code of Laws, which specifies the issues of assigning 
probation, the mandatory and discretionary conditions assigned to the convict, the terms of probation, the grounds for its cancellation [2].

According to US law, probation is applied by a court order under the supervision of special bodies and involves several additional restrictions, such as not visiting certain places, refraining from communicating with certain persons, refraining from possessing a firearm, living in a public correctional institution, prohibiting the possession of the property, participation a convicted person in a public, private or non-profit rehabilitation program, etc.

Control over the behaviour of convicts is carried out by an official. It is widely used through the use of an electronic monitoring device (electronic bracelet), which involves monitoring convicts at home or during work [3].

In Poland, restriction of freedom is served at the place of residence as provided for in the legislation of our Republic. According to part. 2 articles. 34 of the Criminal Code of Poland, while serving a sentence of restraint of liberty, a convicted person:

- Cannot change the place of permanent residence without the consent of the court;

- Is obliged to perform work specified by the court;

- Is obliged to give explanations regarding serving the sentence;

- Loses the right to hold elective positions in public organizations [4].

The court also specifies the obligations to perform public works for an unpaid amount for public purposes specified by the court, at the relevant enterprise, health service facility, social protection, organization or institution providing charitable assistance, or in favour of the local community in the amount of 20 to 40 hours per month. It is noteworthy that for the first time in the process of applying the restriction of freedom, the court takes into account the will of the convicted person regarding the place, time, type and type of work. At the same time, the Court indicates to make deductions from 10 to $25 \%$ of earnings in favour of the state or for public purposes. Obviously, the punishment in the form of restriction of freedom in Polish legislation contains some signs of punishment in the form of forced or corrective labour, and in a more severe version than in our legislation. The convicts are under the supervision of a specialized body. It should be noted that the level of development of such an institution as the restriction of freedom is not the same in all the countries considered. Each country has its own characteristics, both positive and negative.

At present, in our country there is no specific mechanism for the implementation of legal restrictions imposed by the restriction of freedom; it has yet to be created by issuing the relevant norm-setting acts. Taking into account the lack of practice and sufficiently fully formulated scientific explanations of the executive order, serving a sentence in the form of restriction of freedom, scientists will investigate ways to improve the quality and effectiveness of its application. With the complexity and cost of organizing the enforcement in the practice of restraint of liberty at present there is no positive dynamics in the use of electronic means of tracking and supervision of prisoners sentenced to restraint of liberty. Thus, only the convict's 
Doi: https://doi.org/10.37547/tajpslc/Volume03Issue04-27

responsibility for damaging electronic means of control and supervision can affect the development of positive experience with the use of electronic bracelets in the Republic of Uzbekistan.

\section{REFERENCES}

1. https://lex.uz/

2. Shagidullina, Zh.V. (2012). Probation as an alternative to imprisonment as a form of criminal punishment in the United States. Fən-science, (9), 44-47.

3. Shagidullina, J. (2013). Penalty as a type of criminal punishment in the United States. TISBI Bulletin, (1), 207-214.

4. The Criminal Code of the Republic of Poland: [adopted on 01.01.1997]. URL: http://www.crimpravo.ru/page/zar-uk (date of treatment 08/04/2016 